\title{
Geospatial Technology Potentials in Reawakening the Consciousness of Soil Distribution in Nigeria's North-Central Region and Mediating the Herdsmen-Farmers Conflicts
}

\author{
Ugonna C. Nkwunonwo, Francis I. Okeke, Emmanuel N. Chiemelu, Elijah S. Ebinne \\ Department of Geoinformatics \& Surveying, University of Nigeria, Enugu Campus, Enugu, Nigeria \\ Email: ugonna.nkwunonwo@unn.edu.ng, francic.okeke@unn.edu.ng, emmanuel.chiemelu@unn.edu.ng, \\ elijah.ebinne@unn.edu.ng
}

How to cite this paper: Nkwunonwo, U. C., Okeke, F. I., Chiemelu, E. N., \& Ebinne, E. S. (2019). Geospatial Technology Potentials in Reawakening the Consciousness of Soil Distribution in Nigeria's North-Central Region and Mediating the Herdsmen-Farmers Conflicts. Journal of Geoscience and Environment Protection, 7, 156-175. https://doi.org/10.4236/gep.2019.72011

Received: January 18, 2019

Accepted: February 24, 2019

Published: February 27, 2019

Copyright $\odot 2019$ by author(s) and Scientific Research Publishing Inc. This work is licensed under the Creative Commons Attribution International License (CC BY 4.0).

http://creativecommons.org/licenses/by/4.0/

\section{(c) (i) Open Access}

\begin{abstract}
The pervasive herdsmen-farmers conflicts in the north-central region of $\mathrm{Ni}$ geria have changed the narrative of Nigeria's enduring ethnic crises to ideologies, which are in-controvertibly sinister. The consequences of this tension, which has defied possible military responses, political, religious and cultural strategies are potentially devastating, not just for Nigeria, but the whole of West African region. Since the particular nature of these conflicts increasingly highlights the significance and inevitability of land resources for crops farming and cattle rearing, it is imperative to create awareness of the elemental nature of soils, especially their diversities in these conflict-prone areas. This study's objective was to produce a Geographic Information System (GIS) based digital soil map (DSM) of the north-central region of Nigeria, and to delineate soil distribution and unique properties. Based on this study, the DSM offers a quick access to quantitative soil data covering the study area. It indicates that soil mapping units $15 \mathrm{~d}, 18 \mathrm{~d}$ and $24 \mathrm{~b}$ are dominant, and constitute about $40 \%$ of the local arable lands. The broad pattern of distribution of these soils reflects both the climatic conditions and the geological structure of the region. The soils are highly weathered with limited capacities to supply essential nutrients needed by crop plants. These issues raise a number of questions, most of which focuses on the best possible way to maximize these soils to accommodate both crop farming and cattle rearing. It is our hope that taking the advantage of GIS to stimulate the knowledge and consciousness of soil distribution in the region will place the weight where it is appropriate in terms of food security through crops production and cattle rearing, and hence forge a more realistic pathway to reconciliation and conflict resolution.
\end{abstract}




\section{Keywords}

Herdsmen, Sedentary Farmers, North-Central Region of Nigeria, GIS, Digital Soil Map, Food Security, Conflict Resolution

\section{Introduction}

Conflicts between Fulani herdsmen and sedentary farmers scale up the sources of tension for the Nigerian states in recent times (Folami \& Folami, 2013). These conflicts have caused a great deal of loss to human lives, and have resulted in destruction of meaningful livelihood and disruption of mainstream economic activities. Thus, concerns are now on the increase for conflict resolution, risk management and sustainable development (Obioha, 2008; Okoli \& Atelhe, 2014; Adeoye, 2017). Scientists and stakeholders from various human endeavours will find that the complicated nature of these conflicts demands almost the same attentions and resources required to address the changing global climate and its associated natural hazards and disasters which currently appear overpowering for Nigeria and a range of other developing countries (DCs) (Nkwunonwo et al., 2016). This is in addition to various episodes of political crises, social disorders, minor criminalities, and widespread insecurity, which also prevail in Nigeria.

The majority of these conflicts occur within the north central region of Nigeria (Adisa \& Adekunle, 2010; Akinyetun, 2016). This motivates the present study, which in fact, brings to bear enormous considerations for victims of these conflicts and the level of devastation that has occurred over time in this all-important region. By all means possible, this region plays important roles within the geopolitical framework of Nigeria. Its religious and cultural diversity, as well as demographic distribution and human capital resonate well with a secular state, which has great potentials for wealth creation, economic sustainability and nation building. Despite these unique potentials and strategic opportunities for both local and global advantages, the conflict in question have left so much to be desired, and the more disturbing part being the failure of various attempts to assuage the tension and restore peace within the region.

These conflicts are clearly a struggle for land resources (Bello, 2013; Abbass, 2014; Majekodunmi et al., 2014; Dimelu et al., 2016). Whilst land in itself maintains a fixed attribute in supply, the effects of poor resources governance and possible climate change have reduced it to a limited and scarce commodity and a cause of disagreement for related and proximate consumers in the region in question (Amusan et al., 2017). Put in another way, although human beings are engaged in these conflicts, it is ideologically a battle for dominance for either crops or herds. Given that both the Fulani herdsmen and settled farmers have just about the same interests in land resources-a fact that has been sufficiently demonstrated in extant research (for examples Thapa \& Yila, 2012; Idowu, 2017), it thus becomes instructive to imagine a means to settle the dispute on the 
basis of an index or decision criteria, acknowledge by all and sundry. This is the ethos and hypothesis of the present study (schematized in Figure 1), which uses Geographic Information System (GIS) tools and technology to map the soil and delineate its unique properties in the region. This will reawaken the consciousness of conflicted parties and stakeholders to the realities and uniqueness of soil distribution in the area. It will also help to develop a true sense of importance to judge between cattle rearing and crops production in terms of what matters most in respect of food security for the area in particular and Nigeria in general.

GIS or geospatial technology describe a set of tools used to capture, analyse, manipulate and disseminate spatially referenced data. A great deal of studies exists in the literature that considers the application of GIS in various issues that border around human development and the physical environment (Javadian et al., 2011; Sherrouse et al., 2011; Jia et al., 2017; Faridi et al., 2018; Oğuz-Kırca \& Liritzis, 2018). In view of the pervasive herdsmen-farmers conflicts in the north central region of Nigeria, GIS can provide a platform to investigate land classification, water resources, geomorphic features and ecological system. Arguably, these investigations are lacking within the present context, although research has not developed much in view of using GIS to resolve the herdsmen-farmers conflicts. However, the study by Muhammed et al. (2015), which used GIS to associate land with the herdsmen-farmers conflicts in Nigeria, is important, although it largely generalised the land conflicts and makes it hard for anyone to appreciate the issue in specific and particular contexts. Similarly, the study by Shittu et al. (2016) which used GIS to investigate the nature and extent of land use changes and implications on land conflicts considered Gombe state of Nigeria, and did not focus on the north central region of Nigeria. Since no study has so far been directed towards a digital mapping of the soils of the north central region of Nigeria, as a way to mediate the present conflicts, such an objective is the novelty of the present research and also makes significant contributions to the

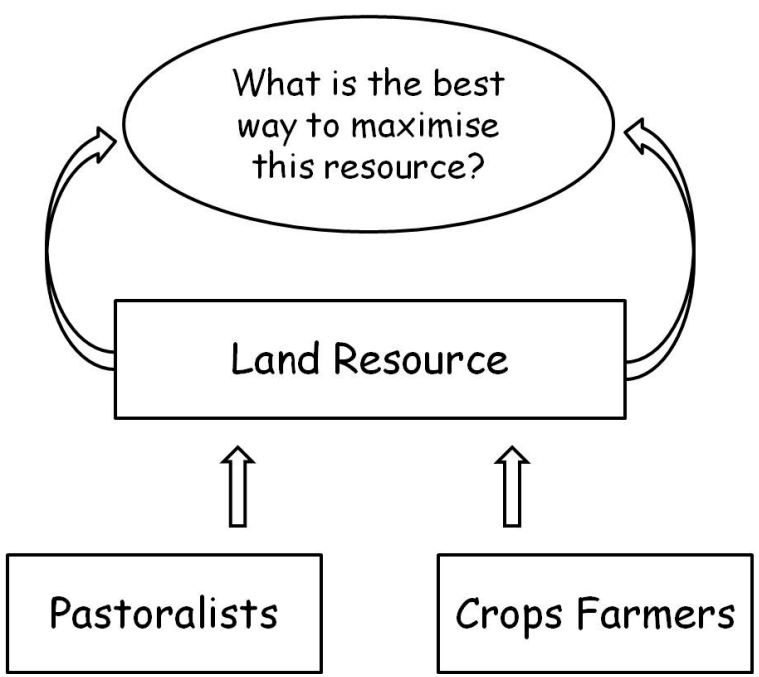

Figure 1. The research ideology and conceptualisation of the major issue of disagreement between herdsmen and farmers in the north central region of Nigeria. 
science of geoinformatics, pedometrics, human ecology and conflicts management. Moreover, the method presented in this research lends itself easily for hybrid and advanced methods of soil analyses which would further pave way for sustainable land development within the conflict-prone areas.

\section{Description of the Study Area and a Brief Review of the Herdsmen-Farmers Conflicts}

The map in Figure 2 shows the location and the constituent areas of the north central region of Nigeria. From the map, the area lies from longitude $2^{\circ} 45^{\prime}$ to $10^{\circ} 38^{\prime}$ East of the GMT and from latitude $6^{\circ} 32^{\prime}$ to $11^{\circ} 21^{\prime}$ North of the equator, altogether enclosing a total landmass of 242,425 sq kilometers (i.e. 93,600 sq miles). This is about the total land area of the whole of United Kingdom. The key place in the map is the bird-shaped Federal Capital Territory (FCT), Abuja, which is the seat of power-Nigeria's capital city, cleverly wedged between three major states-Niger, Kogi and Nasarawa, and occupying a very central position, viewed from the four cardinal corners of the country. The remaining states in the area are Kwara, Benue and Plateau. It seems nature strategically positioned these places in such a way as to foreground the extraordinary scenery and overall topography of Nigeria.

Within the north-central region, there are very important geographic feature and identities. The confluence of Rivers Niger and Benue which is in Kogi state just south of the FCT. Plateau state houses the famous Shere hills, while Kainji dam, a major hydroelectric power station in Nigeria, with its associated game reserve are in Niger state. Grasslands and savannah generally form the predominant vegetation of the region, while the younger granite rocks constitute the main geological formation. The demographic distribution of the region, according to Nigeria's national population commission, shows that nearly twenty-four

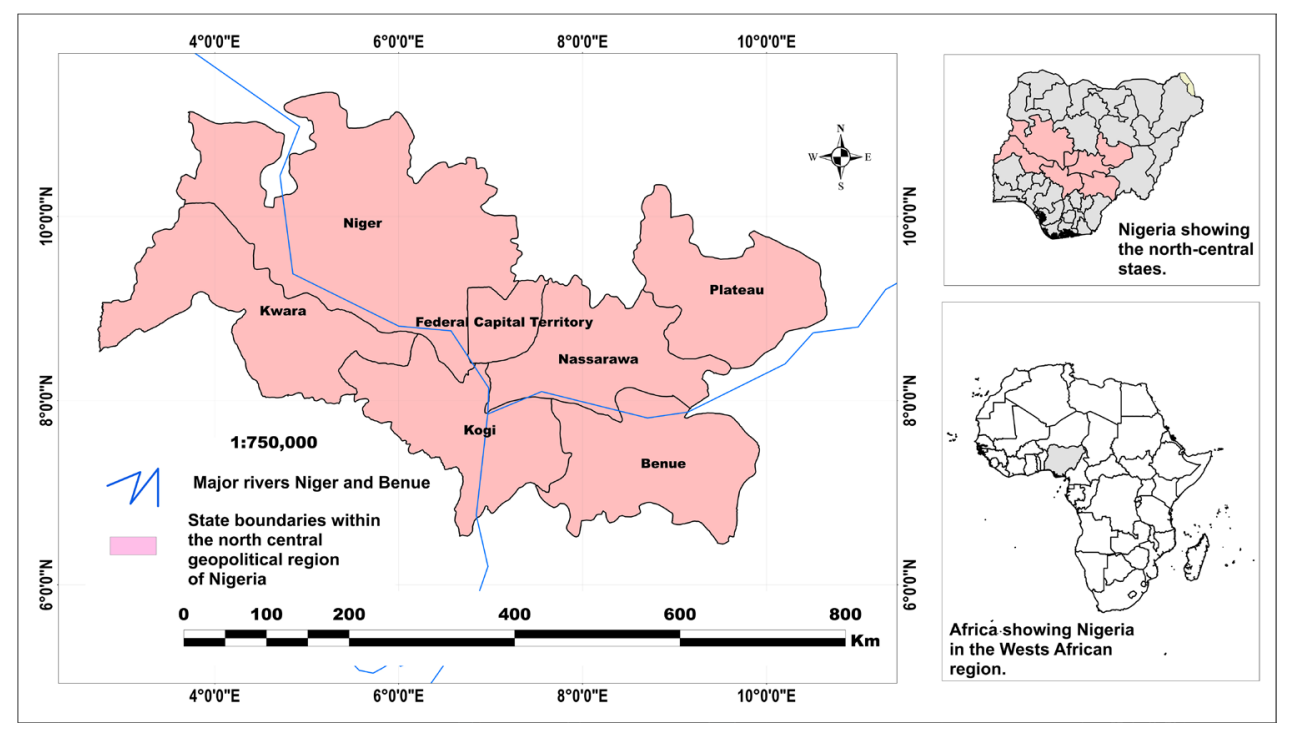

Figure 2. The north central region of Nigeria. Map also shows Nigeria, Africa and the major rivers: Niger and Benue. Source: Drawn by authors. 
million people reside there with a large majority practicing either commercial or subsistence forms of agriculture (NPC, 2007). Although the Hausa/Fulani Muslims dominate the region, the presence of people from other ethnic groups and religions in Nigeria, including the Yoruba and Igbo Christian, create an astonishing variety and diversity. These features and identities along with the picturesque display and spectacular topographic elegance doubtless make the region significant as a major site for tourism, agricultural development, commerce and industrialisation. These are also among the reasons why the pervasive conflicts between Fulani herdsmen and sedentary farmers in this region present a major issue for national development.

Herdsmen-farmers conflicts have remained an ongoing phenomenon in the whole of northern Nigeria since the beginnings of agriculture (Abbass, 2014). Within the north-central region alone, these conflicts seem to have existed for over four decades (Fricke, 1979), although in a seminal study, Blench (2003) posited that the herdsmen-farmer conflict began in earnest in the 20th century. Much of the available knowledge about the spatial and temporary extent of the damage caused by these conflicts is just about anecdotes and journalistic reports. For example, Nigeria's Watch database (cited in Conroy, 2014) showed that more than one thousand six hundred (which is about 58.4\%) violent deaths related to land issues in the Nigeria occurred in region between June 2006 and May 2014, doubtless that more deaths have occurred since then. Although there have been little or no realistic damage assessment based on a detailed scientific investigation, many of the living witnesses in the affected areas believed that in addition to claiming thousands of human lives, these conflicts have also cost millions of United States Dollars (USD) in economic damage. Due to the lack of a realistic damage assessment, many uncertainties surround ascertaining the exact cause of these conflicts. This situation can explain why solutions have so far remained indeterminate. It also justifies the present study, especially as it particularly leveraged on the issue of land resources, which several studies have identified as the main issue of disagreement because of its significance in both cattle rearing and crops farming.

Blench (2003) indicated four major factors that triggered the herdsmen-farmer conflicts, and cateogorised three of them into land issues. These include the collapse of the traditional burti system of cattle routes, the declining importance of dairy production, migration and disease, and the intensification of agriculture in riparian areas known as fadama cultivation. Since then, many recent studies (including Obioha, 2008; Olabode \& Ajibade, 2010; Odoh \& Chigozie, 2012; Folami \& Folami, 2013; Abugu \& Onuba, 2015; Amusan et al., 2017; Tanimu \& Akujuru, 2018) have implicated the changing global climate in the herdsmen-farmers conflicts. Table 1 shows a summary of these studies highlighting their unique contexts and main findings. In particular, the study by Obioha (2008) argued that climate change impacts have been severe in the whole of northern Nigeria, and directly occasioned a clear loss of agrarian lands. This situation forced pastoralists 
Table 1. Summary of key research relating to the causes of Fulani Herdsmen-Farmers conflicts: Contexts and major findings.

\begin{tabular}{|c|c|c|c|}
\hline S/No. & Author(s) & Study & Context/Main findings \\
\hline 1. & Obioha (2008). & $\begin{array}{l}\text { Climate change, population drift } \\
\text { and violent conflict over land } \\
\text { resources in northeastern } \\
\text { Nigeria. }\end{array}$ & $\begin{array}{l}\text { The scarcity of land occasioned by } \\
\text { reduced amount of rainfall is associated } \\
\text { with conflict in the quest available land } \\
\text { resources in the northeastern Nigeria. }\end{array}$ \\
\hline 2. & $\begin{array}{l}\text { Odoh \& } \\
\text { Chigozie } \\
(2012)\end{array}$ & $\begin{array}{l}\text { Climate change and conflict in } \\
\text { Nigeria: a theoretical and } \\
\text { empirical examination of the } \\
\text { worsening incidence of conflict } \\
\text { between Fulani herdsmen and } \\
\text { farmers in Northern Nigeria. }\end{array}$ & $\begin{array}{l}\text { Conflict in northern Nigeria is caused by } \\
\text { natural resource scarcity and climate } \\
\text { change which has through drought and } \\
\text { desertification led to the worsening } \\
\text { incidence of natural resource scarcity }\end{array}$ \\
\hline 3. & $\begin{array}{c}\text { Folami \& } \\
\text { Folami (2013). }\end{array}$ & $\begin{array}{l}\text { Climate change and inter-ethnic } \\
\text { conflict in Nigeria. }\end{array}$ & $\begin{array}{l}\text { Conflicts are due to climate change, } \\
\text { which alters the average weather } \\
\text { condition of the area. }\end{array}$ \\
\hline 4. & $\begin{array}{c}\text { Abugu \& } \\
\text { Onuba (2015). }\end{array}$ & $\begin{array}{l}\text { Climate change and pastoral } \\
\text { conflicts on the middle belt and } \\
\text { southeast Nigeria: Implication on } \\
\text { human resource of the region. }\end{array}$ & $\begin{array}{l}\text { Conflicts are due to climate change, } \\
\text { which occasioned extreme and } \\
\text { unfavourable weather conditions and } \\
\text { thus caused pastoralists to migrate in } \\
\text { search of land resources. }\end{array}$ \\
\hline 5. & $\begin{array}{l}\text { Benjaminsen } \\
\text { (2016). }\end{array}$ & $\begin{array}{l}\text { Does Climate Change Lead to } \\
\text { Conflicts in the Sahel? }\end{array}$ & $\begin{array}{l}\text { Conflicts are in general associated with } \\
\text { state policies, not climate change, which } \\
\text { result in the marginalisation of } \\
\text { pastoralists. State politicians fail to } \\
\text { resolve land issues in areas where } \\
\text { pastoralists and farming overlap as the } \\
\text { main forms of land use. }\end{array}$ \\
\hline 6. & $\begin{array}{l}\text { Amusan et al. } \\
\text { (2017). }\end{array}$ & $\begin{array}{l}\text { Climate change, pastoral } \\
\text { migration, resource governance } \\
\text { and security: the Grazing Bill } \\
\text { solution to farmer-herder } \\
\text { conflict in Nigeria. }\end{array}$ & $\begin{array}{l}\text { Nigeria's federal system of government } \\
\text { downplays the country's diversity, and } \\
\text { further aggravates conflicts and } \\
\text { insecurity such as the present } \\
\text { herdsmen-famers. }\end{array}$ \\
\hline 7. & $\begin{array}{l}\text { Tanimu \& } \\
\text { Akujuru } \\
\text { (2018). }\end{array}$ & $\begin{array}{l}\text { Resolving the } \\
\text { Farmers/Herdsmen conflict in } \\
\text { Southern Kaduna through } \\
\text { sustainable land management } \\
\text { practise. }\end{array}$ & $\begin{array}{l}\text { The absence of grazing and farmland has } \\
\text { been the major cause of the } \\
\text { herdsmen/farmers clash. The study } \\
\text { focuses in Kaduna state. }\end{array}$ \\
\hline
\end{tabular}

and sedentary farmers to migrate to locations where there are more vegetation and abundant water resources to meet the increasing routine demands of cattle and crops. Odoh \& Chigozie (2012), Abbass (2014) and Fasona et al. (2016) alluded to the same idea of climate change but posited that a lack of good governance, widespread insecurity in Nigeria, poverty and corruption are remotely complicit.

In two mutually related studies, which investigate the climate-conflict nexus in detail, Benjaminsen et al. (2012) and Benjaminsen (2016) opposed the idea of climate-induced conflict. Both studies considered a distinct area at the heart of the Sahel, the inland delta of the Niger River in the Mopti region of Mali and reviewed some international research, to assess critically the climate-conflict no- 
tion. In the end, the studies based the conflicts on three structural factors, which are, agricultural intrusion that hindered the mobility of herders and livestock, rural hegemony, which is largely due to an increasing failure of political leadership, corruption and money-grubbing habit among elected and responsible public officers. Dimelu et al. (2016) examined these conflicts in the Kogi side of the north central region, using a sample of 135 crop famers and 72 herdsmen, all selected at random. The outcome of the study indicates that crop farmers attributed the conflicts to mostly uncontrolled grazing and several activities of herdsmen that affect both the harvested crops and the farmland. Likewise, the herdsmen reported that activities of the farmers tend to undermine the livelihood goals of the cattle.

So far, various views within the research relating to the causes of these conflicts are either related or polarised. Although the present research acknowledges these views, authors' interest is in the issues of global climate change (GCC) and dwindling land resources. GCC in recent times impacts on many physical phenomenon and this has been evidenced in the sub-Saharan region, which includes Nigeria. Some of the clear impacts of GCC within this context are increased rainfall frequency and intensity which leads to flooding, gully erosion and depletion of especially arable lands, leading to food insecurity (Kotir, 2011; Serdeczny et al., 2017). GCC also accounts for desert encroachment, scarcity of water, most tropical epidemics, all of which have been associated with the herdsmen-farmers conflicts. Our working principle in the present research suggests that land resources in the north-central region of Nigeria is now a scarce commodity due to the severe effects of climate change. Thus, by presenting a more convenient way of perceiving the soils, understanding the key components, and accessing its data, stakeholders can appreciate how the conflicts can be resolved by scaling up the usefulness of soil on the basis of crop farming and cattle rearing.

\section{Theoretical Framework of Digital Soil Mapping}

Soil mapping is the first step towards maximising the usefulness of soils in any place. Traditionally, this involves identifying, and making graphical representations of the nature, type, properties and potential uses of the different types of soil that occur within a geographical location (Howell et al., 2008). In the past 50 years, many countries of the world have been involved in making maps of their soils to determine the range of soil types in their territory, where the soils occur and how to use them. Over the years, these maps have helped in providing qualitative data for many agro-based projects and scientific issues. Nevertheless, of recent many factors such as increasing population, urbanisation and climate change are putting more and more pressure on available land resources. Thus, the traditional soil maps began to reveal themselves as no longer able to meet with the increasing needs and challenges. This threatens agriculture, food security, and sustainable development in both the developing world as well as the developed world (Arrouays et al., 2014). 
The most important issue with the traditional soil maps is that they are difficult to use, while the method of producing them is slow and expensive. The soil information provided by the maps was subject to much uncertainty because the maps were old and not updated. Moreover, end users of soil information lacked timely access. This, in addition to meeting the challenges of increasing land demand, ensuring a sustainable land use, and ability to take decisive action in issues involving land conflicts such as that of herdsmen-farmers in the north-central region of Nigeria, prompts the need for quick, quantitative, up-to-date and more accurate soil data. Similar to the hardcopy soil map of Nigeria in general, the three sheets-4, 5 and 8 -hardcopy soil map of the north-central region doubtless possess a number of limitations and issues. Such issues as data insecurity, lack of quantitative and accurate soil data, non-flexibility of scale, highly generalized legend, dimensional instability, difficult to use, lack of soil update information, lack of thematic maps of basic soil properties and difficulty in extraction of soil data are major concern in the usefulness of the soil maps. Thus, in spite of the existing soil data provided by these analogue maps, the region arguably still suffers from severe dearth of soil information and spatial data infrastructure. This situation will hinder a realistic understanding of the soils required to address herdsmen-farmers conflicts, which anchors on limited land resources.

Digital soil mapping is a paradigm shift from conventional, qualitative survey mapping techniques to reproducible, fast and cost-effective, quantitative and predictive methods, which leverage on the explosive increase in computation power together with fast developments in data acquisition technology, analytical tools and GIS since the 1980s (Vaysse \& Lagacherie, 2017). It involves the creation and population of a geographically referenced soil databases, production of a digital thematic maps of soil type and soil properties of an area (Menezes et al., 2013). GIS is the main platform for this new soil mapping ideology (Nkwunonwo \& Okeke, 2013). The main idea is to enhance the inclusion of as much secondary (digital) data as possible into GIS with the aim of deriving a digital product. Digital soil map and soil database production for the north central region of Nigeria is believed to provide soil data that will be easily used in a computer system, formulating a system of easy access to the accompanying database and making provision for updating, manipulation, editing, analysis, query and reporting to the internet if need be.

\section{Method and Data}

This study utilised mainly sheets 4, 5 and 8 hardcopy soil maps of Nigeria (with their corresponding processed raster images shown in Figure 3). Each of these hardcopy maps come at a displayable scale of 1:650,000, to enable appreciable clarity of the mapped features. These maps are associated with the Reconnaissance soil survey report of 1990, compiled by the Federal Department of Agricultural Land Resources (FDALR) Abuja, Nigeria (refer to Nkwunonwo \& Okeke, 2013) for a historical sketch of the original soil survey conducted in Nigeria by FDALR between 1986 and 1990. To prepare these analogue datasets for 


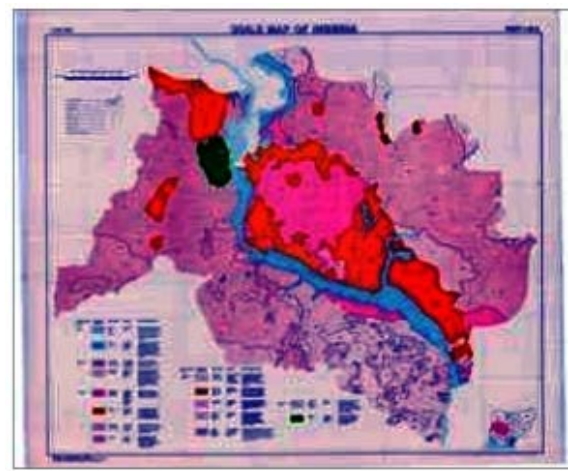

(a)

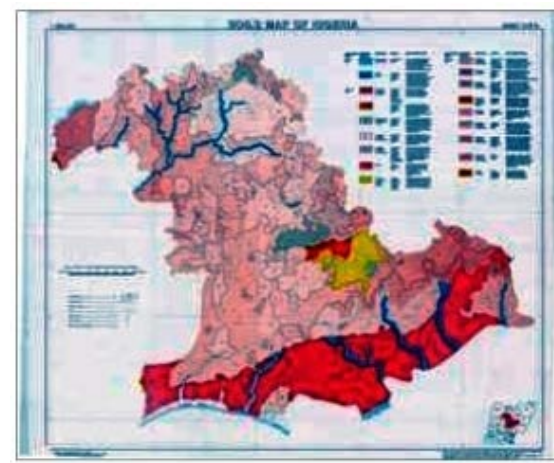

(c)

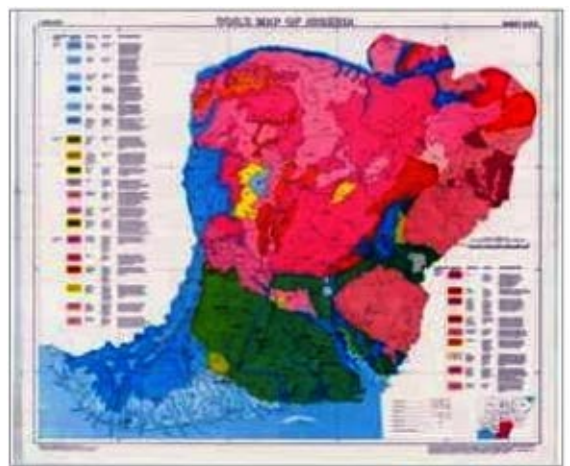

(e)

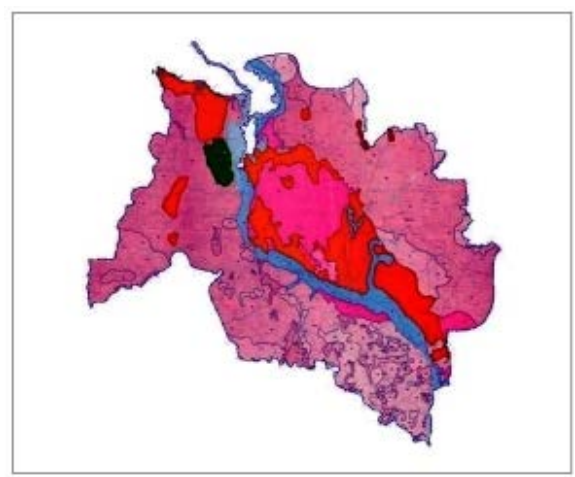

(b)

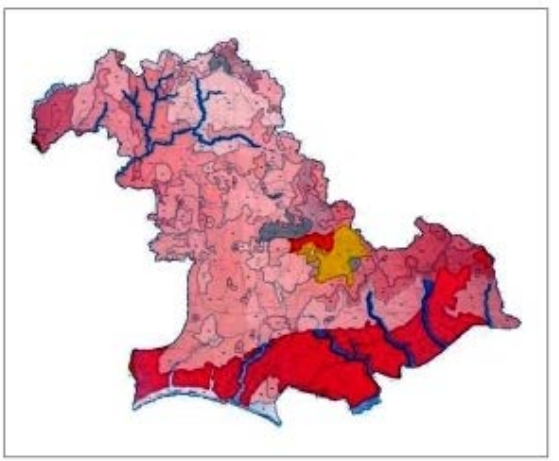

(d)

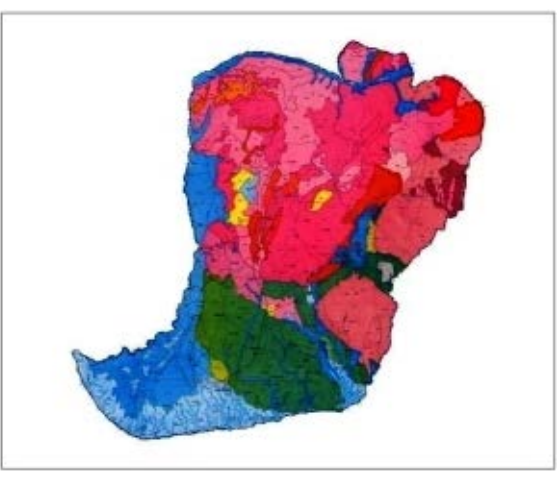

(f)

Figure 3. The sheet 4, 5 and 8 soil map of Nigeria: (a) Sheet 4, (b) the corresponding processed image (c) sheet 5 , (d) the corresponding processed image, (e) sheet 8 and (f) the corresponding processed image.

digital soil mapping, the first step was electronic scanning of the hardcopy soil maps. The scanner is to be set to a very high resolution (in this research, 500 dot per inch) to obtain clear raster digital images. Then georeferencing of the raster images followed. The present research adopted the universally acknowledged WGS 84 coordinate system, and then warped all the scanned raster images to this system. In order to clip off those unnecessary map annotations, prior to extracting the area of interest-that is the north central regions of Nigeria, the resulting raster images were subsequently subject to subset operation. Mosaic operation created a seamless raster layer of the three processed sheets 4,5 and 8 
images showing the spatial extent and coverage within study area. Figure 4 shows the result of this operation and an inset map, which delineates the extent and location within Nigeria, where the mosaicked images represent.

Other datasets, which were necessary for the present study, include the vector map of north-central region, clipped from existing vector political map of Nigeria acquired free from online archives. The GIS operation known as spatial analyst extraction by mask used the north-central vector political map to clip out the specified region of the hard copy soil map from the mosaicked image layer. See Figure 5 for the result of this operation. The next step was onscreen digitising of polygons representing various soil mapping units, shown in the scanned raster soil map of the north-central region. This preceded the creation of the soil database. This study used soil information of the study area, contained in FDALR soil survey report to create and populate the attribute table, and then linked it to the vector polygon layer. Information such as soil mapping unit, geology, slope, soil $\mathrm{pH}$, soil drainage, ecological zones and suitability to mechanized farming, etc were included in the attribute table. The combined soil spatial data, and attribute table form the digital soil database for study area. ESRI ArcGIS 10.5.1 and ERDAS IMAGINE 2016 provided the platform for all GIS operations.

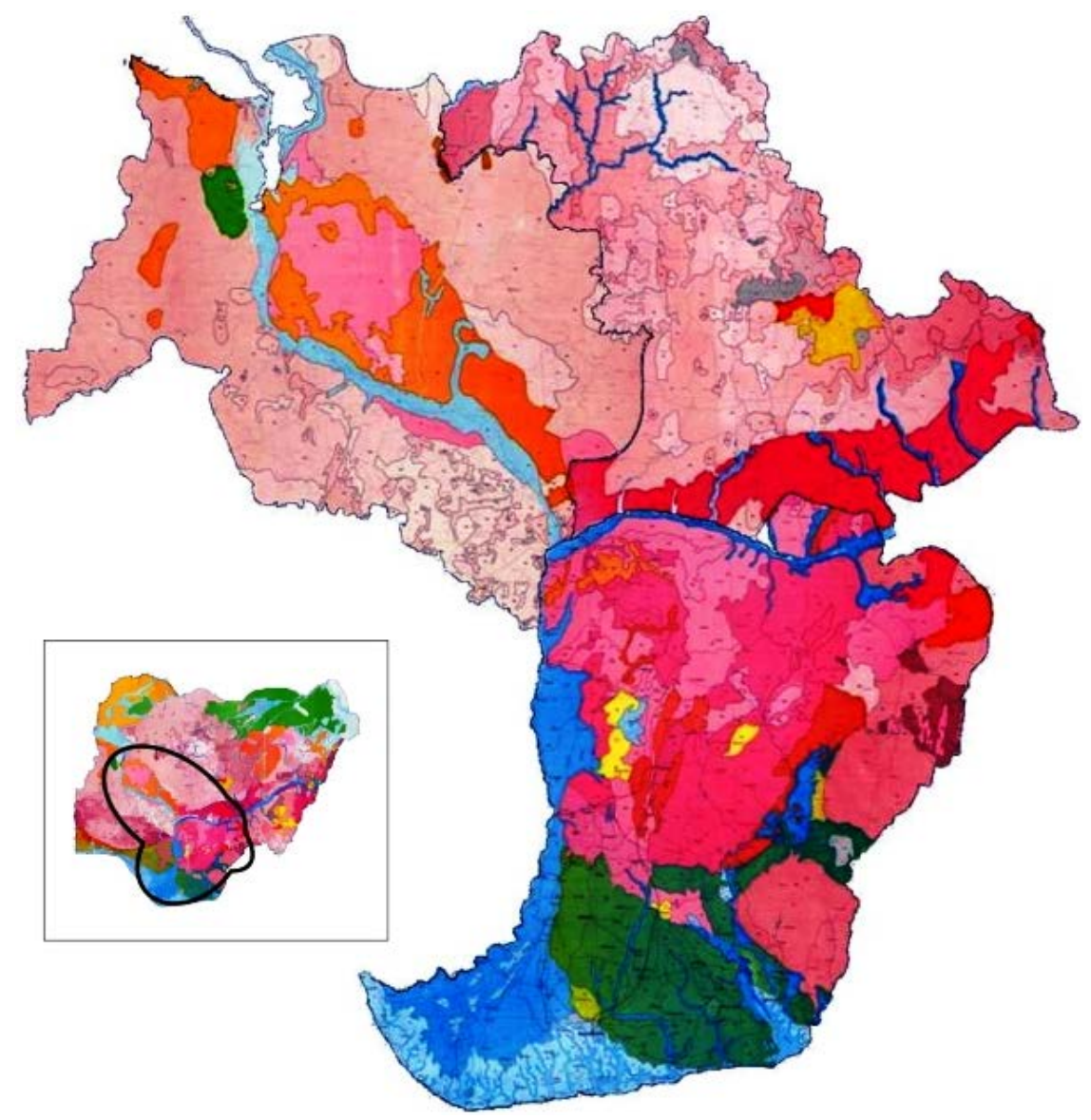

Figure 4. Mosaicked sheets 4, 5 and 8 of the hardcopy soil map of Nigeria 


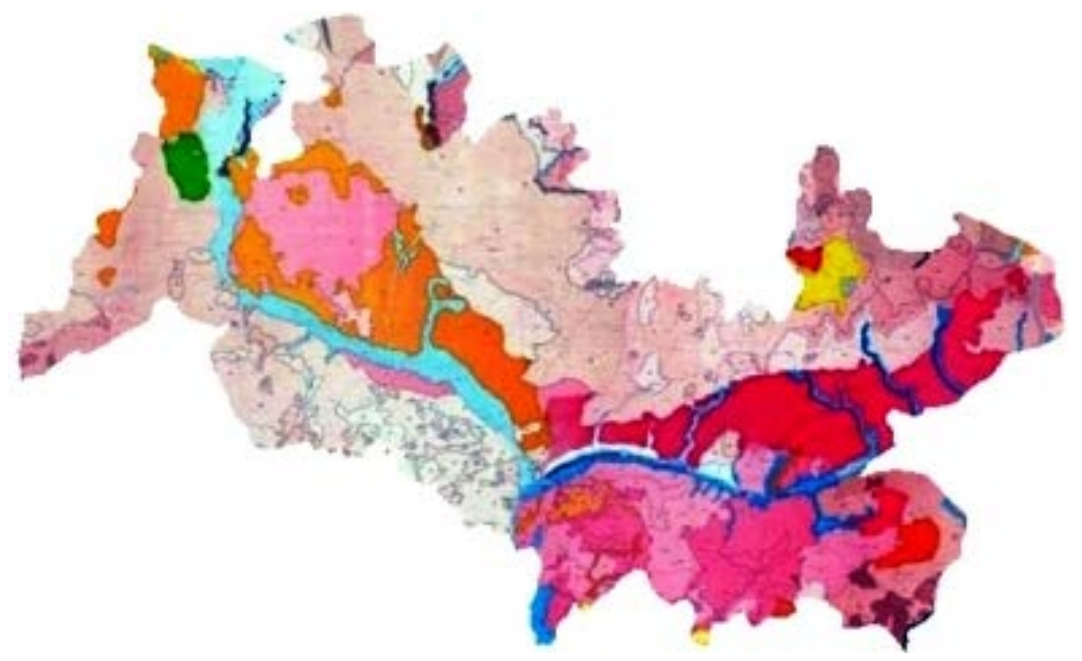

Figure 5. Clipped north central region of the hardcopy soil map of Nigeria.

For optimum utilisation of the database, the present study built some logics and functions into the GIS, which simplified and ensured easy access to the map and provision of information to end users of the digital soil map and soil database of the study area. These logics are queries, written in a structured query language (SQL), and incorporated into the soil database (refer to the appendix for these SQLs). Finally, the soil database (consisting of the spatial data and attribute table) were spatially analysed by means of "semiotic" tool in ArcGIS 10.5.1 to derive various themes (physical and chemical properties) of the DSM. Figure 6 shows the schematics of the ModelBuilder, designed for all the operations carried out within ArcGIS in the present research.

\section{Result and Discussions}

The major result of this study is the digital soil map of north-central region of Nigeria (Figure 7). The result provides quick, accurate, up-to-date and quantitative soil information and reduces the difficulty in the use of the hard copy soil maps of the region. As a digital product, the result is free from dimensional distortion and simplified the manipulation and editing of soil data, viewing of features at various scales, production of thematic maps of various soil properties, improved land suitability evaluation, statistical presentation of numeric soil variables and analysis of soil data with other components like rainfall, temperature and vegetation. It also demonstrates how a geospatial tool can support quick retrieval and presentation as well management of soil data in such a conflict prone area of Nigeria.

From this map, there are twenty-nine soil mapping units, which describe the range of soil physical and chemical properties within the study area. They include, 1d, 2a, 2c, 5d, 8a, 9a, 10a, 15a, 15c, 15d, 15e, 15f, 15g, 17a, 18a, 18c, 18d, 19a, 19c, 20a, 20b, 21a, 21b, 21c, 22a, 22b, 22c, 24a and 24b (see Table 2 for a summary of these findings). Of these soil units, only about ten are significant in the study area, and they include, 2a, 15g, 15e, 19a, 21c, 22c 17a, 15d, 18d, and 


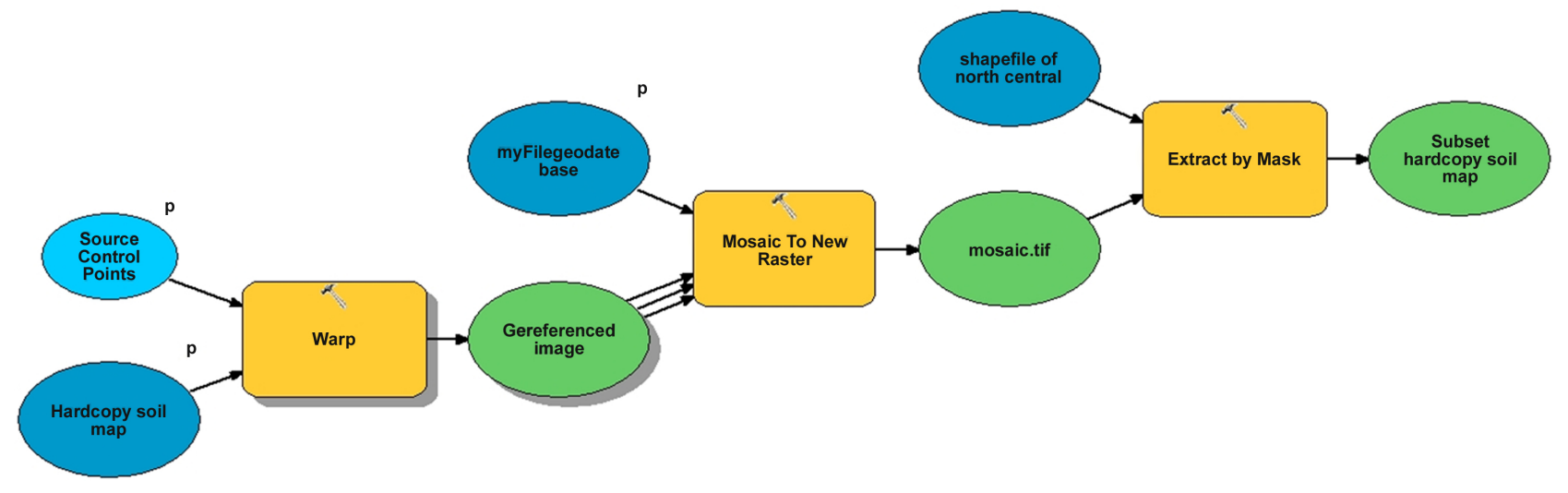

Figure 6. Model Builder of all the operations carried out in ArcGIS in this research. These include Georeferencing (Warp), Mosaic, and Image subset (spatial analyst extraction by Mask). The three arrows represent the three sheets of the hardcopy soil map linking the ellipse showing georeferenced image to the rectangle of mosaicked new raster. Each arrow points in the modeller to the georefernced sheet of the soil map.

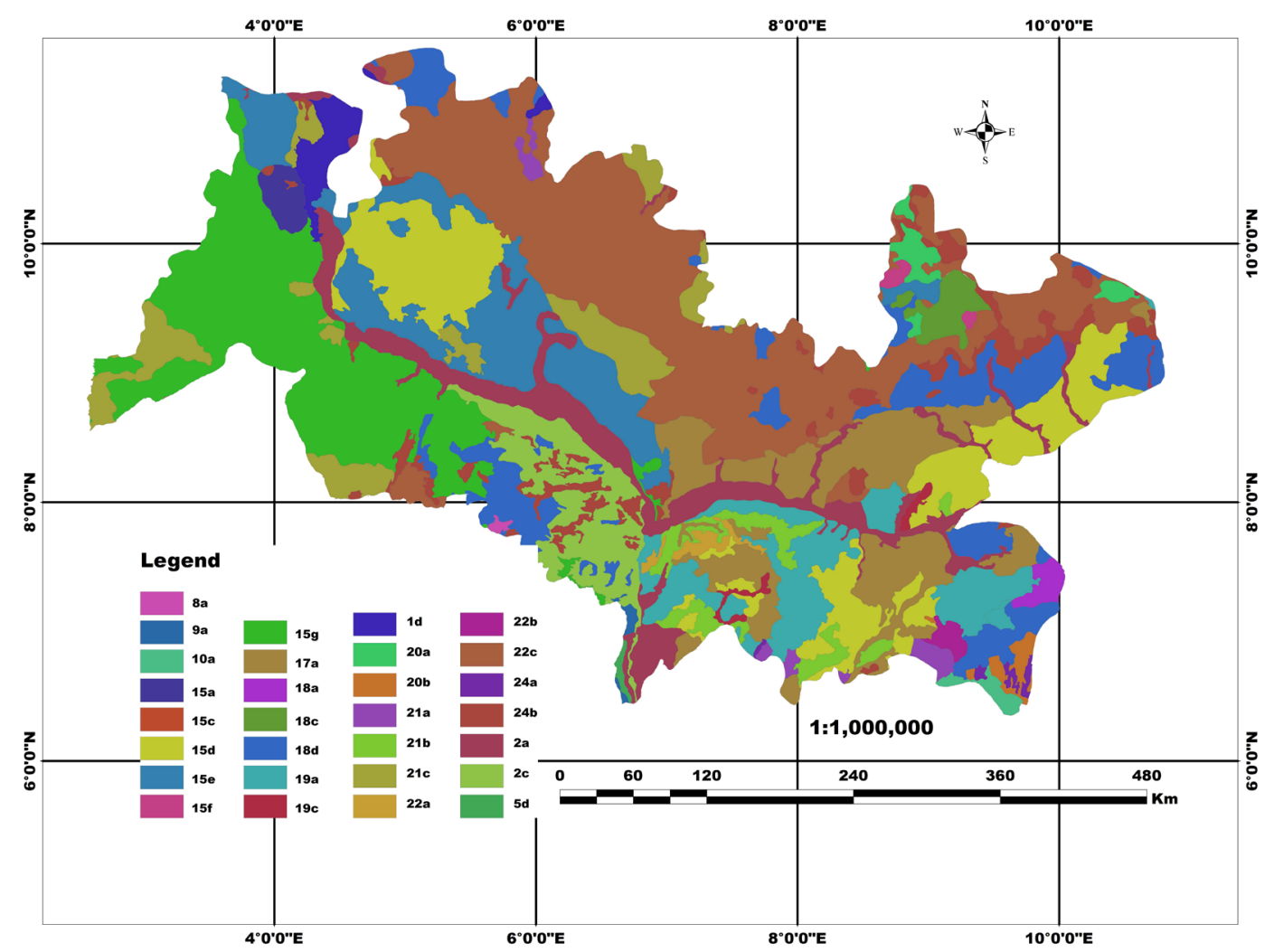

Figure 7. Digital soil map of the north central region of Nigeria showing the soil mapping units and the spatial distribution within the area.

Table 2. Soil mapping units and their spatial distribution within the north central region of Nigeria.

\begin{tabular}{cccc}
\hline S/No. & Soil Mapping Units & Ordinal Distribution & \% Distribution \\
\hline 1 & $1 \mathrm{~d}$ & 2 & 1.005 \\
2 & $2 \mathrm{a}$ & 8 & 4.020 \\
3 & $2 \mathrm{c}$ & 1 & 0.503 \\
\hline
\end{tabular}




\section{Continued}

\begin{tabular}{|c|c|c|c|}
\hline 4 & $5 \mathrm{~d}$ & 1 & 0.503 \\
\hline 5 & $8 a$ & 1 & 0.503 \\
\hline 6 & $9 a$ & 2 & 1.005 \\
\hline 7 & $10 \mathrm{a}$ & 1 & 0.503 \\
\hline 8 & $15 a$ & 1 & 0.503 \\
\hline 9 & $15 c$ & 1 & 0.503 \\
\hline 10 & $15 \mathrm{~d}$ & 16 & 8.040 \\
\hline 11 & $15 \mathrm{e}$ & 9 & 4.523 \\
\hline 12 & $15 f$ & 2 & 1.005 \\
\hline 13 & $15 \mathrm{~g}$ & 8 & 4.020 \\
\hline 14 & $17 a$ & 13 & 6.533 \\
\hline 15 & $18 \mathrm{a}$ & 1 & 0.503 \\
\hline 16 & $18 \mathrm{c}$ & 2 & 1.005 \\
\hline 17 & $18 \mathrm{~d}$ & 23 & 11.558 \\
\hline 18 & $19 a$ & 10 & 5.025 \\
\hline 19 & $19 \mathrm{c}$ & 2 & 1.005 \\
\hline 20 & $20 \mathrm{a}$ & 4 & 2.010 \\
\hline 21 & $20 \mathrm{~b}$ & 3 & 1.508 \\
\hline 22 & $21 \mathrm{a}$ & 6 & 3.015 \\
\hline 23 & $21 b$ & 5 & 2.513 \\
\hline 24 & $21 c$ & 11 & 5.528 \\
\hline 25 & $22 \mathrm{a}$ & 2 & 1.005 \\
\hline 26 & $22 \mathrm{~b}$ & 1 & 0.503 \\
\hline 27 & $22 c$ & 11 & 5.528 \\
\hline 28 & $24 \mathrm{a}$ & 5 & 2.513 \\
\hline 29 & $24 \mathrm{~b}$ & 47 & 23.618 \\
\hline
\end{tabular}

$24 \mathrm{~b}$, and three of these including mapping units $15 \mathrm{~d}, 18 \mathrm{~d} 4$ and $24 \mathrm{~b}$ appear to be the most dominant. Their percentage distributions in the study area are $8.04 \%$, $11.56 \%$, and $23.62 \%$ respectively.

Queries incorporated into the new digital soil map and database of the north-central region of Nigeria, in the form of structured query language (SQL) enabled the creation of some thematic maps of relevant thematic significance such as the chemical and physical properties of the soils in the area. Figure 8 shows some important thematic maps extracted from the digital soil map of the region.

The queries also helped the extraction and investigation of the physical and chemical properties of the dominant soil mapping units. Table 3 shows the properties extracted from the DSM and soil digital soil database of the region 


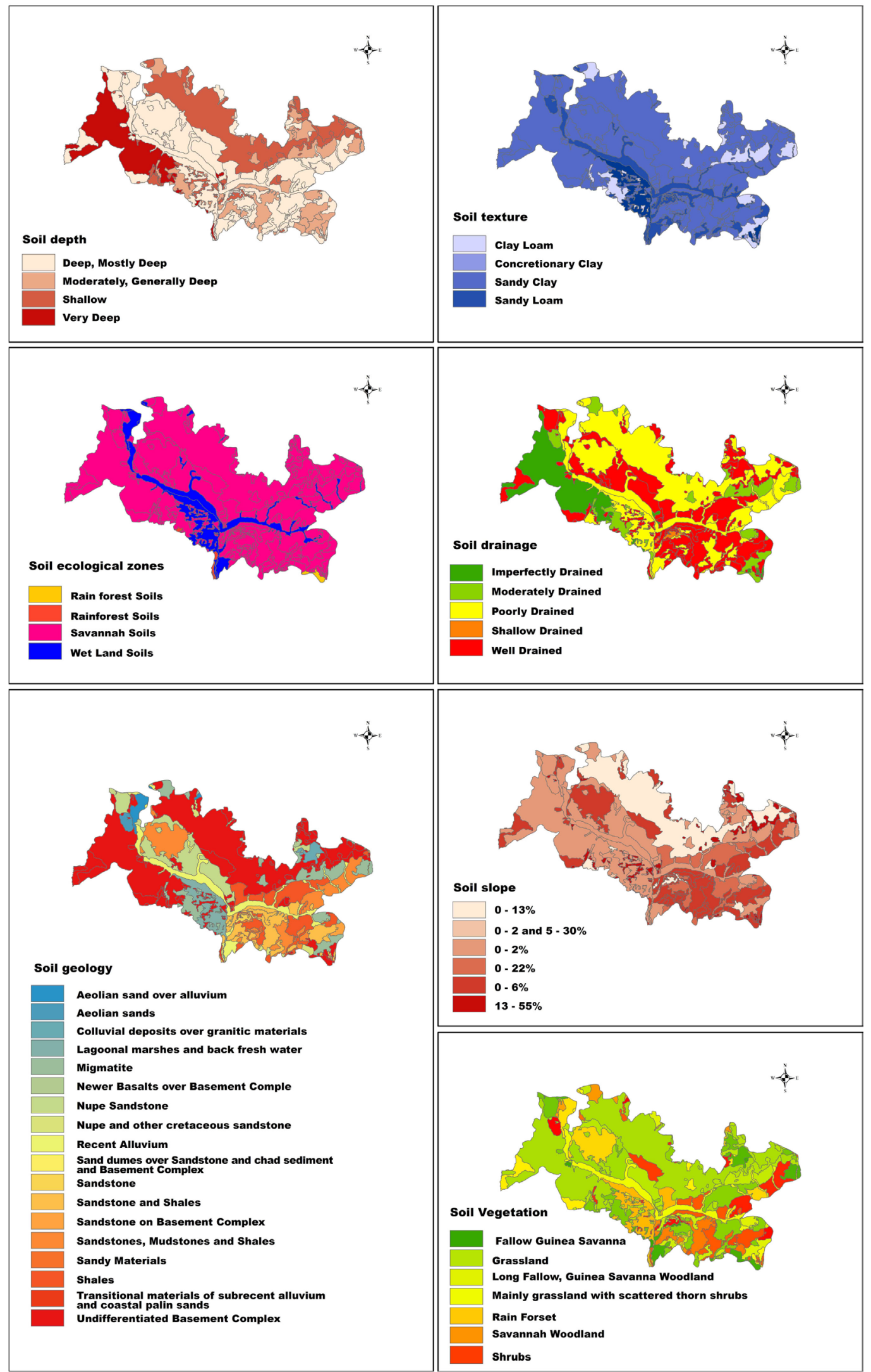

Figure 8. Thematic maps extracted from the digital soil map of the north central region of Nigeria using the SQL syntax. 
Table 3. Soil properties extracted for the soil mapping units $15 \mathrm{~d}, 18 \mathrm{~d}$ and $24 \mathrm{~b}$.

\begin{tabular}{|c|c|c|c|c|}
\hline S/No & Soil Properties & $15 \mathrm{~d}$ & $18 \mathrm{~d}$ & $24 \mathrm{~b}$ \\
\hline 1 & Geology & Sandstone & Migmatite & $\begin{array}{c}\text { Undifferentiated } \\
\text { Basement Complex }\end{array}$ \\
\hline 2 & Slope & $0 \%-6 \%$ & $0-2 \%$ & $13-55 \%$ \\
\hline 3 & Ecological Zone & Savannah & Savannah & Savannah \\
\hline 4 & Drainage & Poorly drained & Moderately drained & Well drained \\
\hline 5 & Soil pH & $6.6-7.3$ & $5.5-6.3$ & $5.1-6.6$ \\
\hline 6 & pH Description & $\begin{array}{l}\text { Slightly acidic to } \\
\text { Neutral }\end{array}$ & $\begin{array}{c}\text { Strongly acidic to slightly } \\
\text { Acidic }\end{array}$ & $\begin{array}{l}\text { Strongly acidic to } \\
\text { slightly Acidic }\end{array}$ \\
\hline 7 & Soil depth & Deep, Mostly Deep & $\begin{array}{c}\text { Moderately, Generally } \\
\text { Deep }\end{array}$ & Shallow \\
\hline 8 & $\begin{array}{l}\text { Suitability for } \\
\text { mechanized } \\
\text { farming }\end{array}$ & $\begin{array}{c}\text { Fairly highly suitable } \\
\text { with few physical } \\
\text { limitation }\end{array}$ & Moderately suitable & $\begin{array}{l}\text { Currently not suit- } \\
\text { able }\end{array}$ \\
\hline 9 & Soil texture & Sandy Clay & Clay Loam & Sandy Clay \\
\hline 10 & Soil classification & Lithic Haplustalf & Ustoxic Dystropept & Typic Tropaquent \\
\hline 11 & Vegetation & $\begin{array}{l}\text { Open savannah } \\
\text { woodland }\end{array}$ & Guinea Corn & Grassland \\
\hline 12 & $\begin{array}{c}\text { Major crops it can } \\
\text { support }\end{array}$ & $\begin{array}{l}\text { Vegetables, Sorghum, } \\
\text { Yam, Maize, Rice, Cow } \\
\text { Pea, Millet, Cotton, } \\
\text { Banana }\end{array}$ & $\begin{array}{l}\text { Sugarcane, Cassava, Yam, } \\
\text { Irish potatoes, Cocoa, } \\
\text { Rubber, Groundnut, } \\
\text { Millet, Sorghum, } \\
\text { Cowpea, Rice, Oil Palm }\end{array}$ & $\begin{array}{l}\text { Sorghum, Millet, } \\
\text { Cowpea, Cotton, } \\
\text { Groundnuts, Beans, } \\
\text { Maize, Yam }\end{array}$ \\
\hline
\end{tabular}

based on the SQL. 1) Geology (undifferentiated (basement complex, sandstone, Migmatite), 2) drainage pattern (well drained, poorly drained, moderately drained), 3) slope (plains, undulating, mountainous, etc.), 4) soil pH (mainly acidic, slightly acidic, neutral) 5) Ecological zones (wetland, rainforest, savannah). In addition, this study extracted and investigated the suitability of the region for mechanized farming using SQL queries. The result shows that the majority of places within the region are fairly highly suitable, moderately suitable and areas that are currently not suitable for mechanized farming. Finally, the queries extracted all places within the region with potential to support the growth of particular crops and vegetative cover such as yam cassava, fruits, potatoes, plantain, rice, maize, etc.

Based on these results, it is perceptible that the broad pattern of soil distribution reflects both the climatic conditions as well as the geological structure in the region. The soils are general highly weathered with limited capacities for supplying the nutrients elements needed by crop plants. In all, the dominant soil mapping units make up about $40 \%$ of the arable lands in the region. This is clearly a limited resource considering the need for agriculture and cattle rearing, and therefore raises a number of questions applicable to identifying the best possible way to maximize these soils, and the means to prioritize land allocation in view of crops farming and animal husbandry. Okeke (2014) reported that un- 
der the British rule, the pastoralists got a fair share of migration and grazing zones, but these appeared to have disappeared through a mix-up of corrupt land allocation and the soaring population of sedentary farmers across different localities within the country. However, possible way to reclaim these previous grazing routes from the current land uses remains a debatable issue. These are key questions that the situation of soil distribution in the north-central region of Nigeria puts up in relation to the herdsmen-farmers conflicts. However, the present research, through its provision of a quick, quantitative and adaptable digital soil map of Nigeria's north-central region, can serve as a tool to address these issues, and also catalyze the achievements of sustainable development of human and land resources within the region.

\section{Conclusion}

Herdsmen-Farmers conflict in the north central region of Nigeria is a major challenge which requires attention with regards to sustainable development, capacity building (especially for local communities towards food security and improved means of livelihood) and improved efforts of various stake holders for better resolution of the conflict. Based on the knowledge that land resources are the main cause of disagreement as herdsmen and farmers needs overlap, the present study hypothesizes that mapping of the soil distribution in the area and delineation of the soil chemical and physical properties can provide a way to address the increasing land resources scarcity occasioned mostly by climate change.

The present study thus demonstrates the use of GIS technology to produce a digital soil map (DSM) of the north central region of Nigeria, a soil database and digital map of various associated themes of soil chemical and physical properties. The new DSM, which is the main result of this study, provides a quick access to accurate, quantitative and editable soil information. It also shows that there are twenty-nine soil mapping units, within the study area. Of these soil units, only about ten are significant, and three of them, including $15 \mathrm{~d}, 18 \mathrm{~d}$ and $24 \mathrm{~b}$ appear to be the most dominant. Their percentage distributions in the study area are $8.04 \%, 11.56 \%$, and $23.62 \%$ respectively. The overall pattern of distribution of these dominant soil units indicates a reflection of both climatic and geologic structure of the region.

Digital soil mapping as a way of mediating the herdsmen-farmers conflicts in this all-important region of Nigeria is the novelty of the present study as well as a significant contribution to knowledge in the areas of geoinformatics, human ecology, pedometrics and conflict resolution. However, the issues of that surrounds soils properties within the regions presents enormous questions, most of which relates to how to maximise the soil potential in a way to accommodate both the herdsmen and sedentary farmers. This study did not answer these questions as they are beyond our objectives. However, it recommends them for further studies. This study is limited to production of DSM using GIS technique. There was no attempt to investigate the suitability of the soils for any particular 
agricultural purpose. However, we recommend a further study, which can take advantage of the data provided by this study and bring to bear expert knowledge in the fields of agriculture and soil science to fill this gap.

\section{Acknowledgements}

This research got its fund and grants from the National Space Research and Development Agency (NASRDA) through the project titled, "Early warning for Food Security for Nigeria using NigeriaSat1 and other Satellite Imageries", in which NASRDA and the department of Geoinformatics and Surveying, University of Nigeria Nsukka were co-collaborators. The Federal Department of Agricultural Land Resources (FDALR) provided the hardcopy soil map of Nigeria and its associated baseline report. Map Library, an open source online platform for shapefiles vector maps permitted the use of the vector political map of Nigeria, as the basemap for the study area. This research enjoys the fortune of numerous contributions from many previous researches, for which the present authors are profoundly grateful. Finally, the authors acknowledge most sincerely the editor of this journal and the anonymous reviewer(s) of this paper.

\section{Conflicts of Interest}

The authors declare no conflicts of interest regarding the publication of this paper.

\section{References}

Abbass, I. M. (2014). No Retreat No Surrender Conflict for Survival between Fulani Pastoralists and Farmers in Northern Nigeria. European Scientific Journal, ESJ, 8, 331-346.

Abugu, S. O., \& Onuba, C. O. (2015). Climate Change and Pastoral Conflicts on the Middle Belt and South-East Nigeria: Implication on Human Resource of the Region. Global Journal of Human Resource Management, 5, 44-51.

Adeoye, N. O. (2017). Land Use Conflict between Farmers and Herdsmen in Parts of Kano, Yobe and Borno States of Nigeria: Nomads' Viewpoints. Ghana Journal of Geography, 9, 127-151.

Adisa, R. S., \& Adekunle, O. A. (2010). Farmer-Herdsmen Conflicts: A Factor Analysis of Socio-Economic Conflict Variables among Arable Crop Farmers in North Central Nigeria. Journal of Human Ecology, 30, 1-9. https://doi.org/10.1080/09709274.2010.11906266

Akinyetun, T. S. (2016). Staff to Gun: Fulani Herdsmen in Nigeria. Asian Journal of Multidisciplinary Studies, 4, 38-44.

Amusan, L., Abegunde, O., \& Akinyemi, T. E. (2017). Climate Change, Pastoral Migration, Resource Governance and Security: The Grazing Bill Solution to Farmer-Herder Conflict in Nigeria. Environmental Economics, 8, 35-45.

https://doi.org/10.21511/ee.08(3).2017.04

Arrouays, D., McKenzie, N., de Forges, A. R., Hempel, J., \& McBratney, A. B. (2014). GlobalSoilMap: Basis of the Global Spatial Soil Information System. London: CRC Press. https://doi.org/10.1201/b16500

Bello, A. U. (2013). Herdsmen and Farmers Conflicts in North-Eastern Nigeria: Causes, 
Repercussions and Resolutions. Academic Journal of Interdisciplinary Studies, 2, 129139. https://doi.org/10.5901/ajis.2013.v2n5p129

Benjaminsen, T. A. (2016). Does Climate Change Lead to Conflicts in the Sahel? The End of Desertification? (pp. 99-116). Berlin, Heidelberg: Springer. https://doi.org/10.1007/978-3-642-16014-1_4

Benjaminsen, T. A., Alinon, K., Buhaug, H., \& Buseth, J. T. (2012). Does Climate Change Drive Land-Use Conflicts in the Sahel? Journal of Peace Research, 49, 97-111. https://doi.org/10.1177/0022343311427343

Blench, R. (2003). The Transformation of Conflict between Pastoralists and Cultivators in Nigeria. http://www.rogerblench.info

Conroy, S. (2014). Land Conflicts and Lethal Violence in Nigeria: Patterns, Mapping and Evolution (2006-2014). IFRA-Nigeria Working Papers Series, Abuja: IFRA, 38.

Dimelu, M. U., Salifu, E. D., \& Igbokwe, E. M. (2016). Resource Use Conflict in Agrarian Communities, Management and Challenges: A Case of Farmer-Herdsmen Conflict in Kogi State, Nigeria. Journal of Rural Studies, 46, 147-154.

https://doi.org/10.1016/j.jrurstud.2016.06.011

Faridi, M., Verma, S., \& Mukherjee, S. (2018). Integration of GIS, Spatial Data Mining, and Fuzzy Logic for Agricultural Intelligence. In Soft Computing: Theories and Applications (pp. 171-183). Singapore: Springer.

https://doi.org/10.1007/978-981-10-5687-1_16

Fasona, M., Eniola, F., Comfort, S., Vide, A., Felix, O., Peter, O. E., John, O., \& Grace, O. (2016). Some Dimensions of Farmers'-Pastoralists' Conflicts in the Nigerian Savannah. Journal of Global Initiatives: Policy, Pedagogy, Perspective, 10, 87-108.

Folami, O. M., \& Folami, A. O. (2013). Climate Change and Inter-Ethnic Conflict in Nigeria. Peace Review, 25, 104-110. https://doi.org/10.1080/10402659.2013.759783

Fricke, W. (1979). Cattle Husbandry in Nigeria: A Study of Its Ecological Conditions and Social-Geographical Differentiations. Heidelberger Geographischen Arbeiten, Heft 52. Heidelberg: Geographisches Institut der Universität.

Howell, D., Kim, Y. G., \& Haydu-Houdeshell, C. A. (2008). Development and Application of Digital Soil Mapping within Traditional Soil Survey: What Will It Grow into? In Digital Soil Mapping with Limited Data (pp. 43-51). Dordrecht: Springer. https://doi.org/10.1007/978-1-4020-8592-5_4

Idowu, I. D. (2017). Causes, Consequences and Resolution of Environmental Conflicts in Nigeria. International Journal of Social Sciences and Economic Research, 2, 2063-2076.

Javadian, M., Shamskooshki, H., \& Momeni, M. (2011). Application of Sustainable Urban Development in Environmental Suitability Analysis of Educational Land Use by Using AHP and GIS in Tehran. Procedia Engineering, 21, 72-80. https://doi.org/10.1016/j.proeng.2011.11.1989

Jia, P., Cheng, X., Xue, H., \& Wang, Y. (2017). Applications of Geographic Information Systems (GIS) Data and Methods in Obesity-Related Research. Obesity Reviews, 18, 400-411. https://doi.org/10.1111/obr.12495

Kotir, J. H. (2011). Climate Change and Variability in Sub-Saharan Africa: A Review of Current and Future Trends and Impacts on Agriculture and Food Security. Environment, Development and Sustainability, 13, 587-605. https://doi.org/10.1007/s10668-010-9278-0

Majekodunmi, A. O., Fajinmi, A., Dongkum, C., Shaw, A. P., \& Welburn, S. C. (2014). Pastoral Livelihoods of the Fulani on the Jos Plateau of Nigeria. Pastoralism, 4, 1-16. https://doi.org/10.1186/s13570-014-0020-7 
Menezes, M. D. D., Silva, S. H. G., Owens, P. R., \& Curi, N. (2013). Digital Soil Mapping Approach Based on Fuzzy Logic and Field Expert Knowledge. Ciência e Agrotecnologia, 37, 287-298. https://doi.org/10.1590/S1413-70542013000400001

Muhammed, I., Ismaila, A. B., \& Bibi, U. M. (2015). An Assessment of Farmer-Pastoralist Conflict in Nigeria Using GIS. International Journal of Engineering Science Invention, 4, 23-33.

National Population Commission (NPC) (2007). 2006 Population and Housing Census: National and State Population and Housing Tables: Priority Tables I-IV. Abuja: Federal Government of Nigeria.

Nkwunonwo, U. C., \& Okeke, F. I. (2013). GIS-Based Production of Digital Soil Map for Nigeria. Ethiopian Journal of Environmental Studies and Management, 6, 498-506. https://doi.org/10.4314/ejesm.v6i5.7

Nkwunonwo, U. C., Whitworth, M., \& Baily, B. (2016). A Review and Critical Analysis of the Efforts towards Urban Flood Risk Management in the Lagos Region of Nigeria. Natural Hazards and Earth System Sciences, 16, 349-369.

https://doi.org/10.5194/nhess-16-349-2016

Obioha, E. E. (2008). Climate Change, Population Drift and Violent Conflict over Land Resources in North-Eastern Nigeria. Journal of Human Ecology, 23, 311-324. https://doi.org/10.1080/09709274.2008.11906084

Odoh, S. I., \& Chigozie, C. F. (2012). Climate Change and Conflict in Nigeria: A Theoretical and Empirical Examination of the Worsening Incidence of Conflict between Fulani Herdsmen and Farmers in Northern Nigeria. Arabian Journal of Business Management Review, 2, 110-124. https://doi.org/10.12816/0002246

Oğuz-Kırca, E. D., \& Liritzis, I. (2018). Searching Ancient Territorium of Hygassos in Anatolia: Settlement Patterns and Spatio-Temporal Investigations through Aerial and GIS Applications. GeoJournal, 83, 441-464. https://doi.org/10.1007/s10708-017-9779-6

Okeke, O. E. (2014). Conflicts between Fulani Herders and Farmers in Central and Southern Nigeria: Discourse on Proposed Establishment of Grazing Routes and Reserves. AFRREV IJAH: An International Journal of Arts and Humanities, 3, 66-84.

Okoli, A. C., \& Atelhe, G. A. (2014). Nomads against Natives: A Political Ecology of Herder/Farmer Conflicts in Nasarawa State, Nigeria. American International Journal of Contemporary Research, 4, 76-88.

Olabode, A. D., \& Ajibade, L. T. (2010). Environment Induced Conflict and Sustainable Development: A Case of Fulani-Farmers' Conflict in Oke-Ero LGAS, Kwara State, Nigeria. Journal of Sustainable Development in Africa, 12, 259-273.

Serdeczny, O., Adams, S., Baarsch, F., Coumou, D., Robinson, A., Hare, W., Schaeffer, M., Perrette, M., \& Reinhardt, J. (2017). Climate Change Impacts in Sub-Saharan Africa: From Physical Changes to Their Social Repercussions. Regional Environmental Change, 17, 1585-1600. https://doi.org/10.1007/s10113-015-0910-2

Sherrouse, B. C., Clement, J. M., \& Semmens, D. J. (2011). A GIS Application for Assessing, Mapping, and Quantifying the Social Values of Ecosystem Services. Applied Geography, 31, 748-760. https://doi.org/10.1016/j.apgeog.2010.08.002

Shittu, W. J., Galtima, M., \& Yakubu, D. (2016). The Application of Geospatial Analytical Techniques in the Assessment of Land Use Conflicts among Farmers and CrossBoundary Nomadic Cattle Herders in the Gombe Region, Nigeria. Journal of Global Initiatives: Policy, Pedagogy, Perspective, 10, 123-142.

Tanimu, M. Y., \& Akujuru, V. A. (2018). Resolving the Farmers/Herdsmen Conflict in Southern Kaduna through Sustainable Land Management Practise. Crops, 3, 9-20.

Thapa, G. B., \& Yila, O. M. (2012). Farmers' Land Management Practices and Status of 
Agricultural Land in the Jos Plateau, Nigeria. Land Degradation \& Development, 23, 263-277. https://doi.org/10.1002/ldr.1079

Vaysse, K., \& Lagacherie, P. (2017). Using Quantile Regression Forest to Estimate Uncertainty of Digital Soil Mapping Products. Geoderma, 291, 55-64.

https://doi.org/10.1016/j.geoderma.2016.12.017

\section{Appendix}

Some common examples of the Structured Query Language (SQL) used in the present digital soil map (DSM) of Nigeria's north-central region

Query 1: [Geology] = "Undifferentiated Basement Complex" AND "Sandstone" = "Undifferentiated Basement Complex and Sandstone"

Query 2: [Drainage] = "Well Drained" = "Well Drained"

Query 3: [pH Description] = "Very Strongly Acidic" = "Very Strongly Acidic"

Query 4: [Texture] = "Clay Loam" = "Clay Loam"

Query 5: [Ecology] = "Rain Forest Soils" = "Rain Forest Soils"

Query 6: [Crops] = "Maize and Cassava" = "Maize and Cassava"

Query 7: [Vegetation] = "Guinea corn" = "Guinea corn"

Query 6: [Suitability for mechanized farming] = "Moderately Suitable" 